\title{
'Numismatist's pneumonitis.' A case of acute nitrogen dioxide poisoning
}

\author{
K. Sriskandan \& K.W. Pettingale \\ The Medical Unit, King's College School of Medicine and Dentistry, London, SE5 9RS, UK.
}

\author{
Summary: A case of acute nitrogen dioxide toxicity is described, together with its management and a \\ review of the possible complications.
}

\section{Introduction}

Acute nitrogen dioxide $\left(\mathrm{NO}_{2}\right)$ poisoning has been described in many occupational settings; in farmers, as silo-fillers disease (Lowry \& Schuman, 1956); oxyacetylene welders, miners, chemical workers (Jones et al., 1973), missile workers (Yockey et al., 1980) and firemen (Tse \& Bockman, 1970). We report what we believe to be the first case of acute $\mathrm{NO}_{2}$ toxicity in a coin collector.

\section{Case report}

A 77 year old retired building foreman and ex-50/day cigarette smoker with a history of mild chronic obstructive airways disease was cleaning some predecimal pennies at home, using a mixture of $50 \%$ concentrated nitric acid and $50 \%$ water in a tray. He accidentally dropped all the coins into the mixture at the same time. A vigorous reaction ensued, and clouds of a brown-coloured gas were given off. He picked up the tray, carried it slowly to the bathroom, and poured the liquid contents away. He described an attack of coughing at the time, productive of a small amount of brown sputum. On retiring to bed he was unable to sleep, and $2 \mathrm{~h}$ later had rigors, nausea and dyspnoea on slight exertion.

Twelve hours after the incident he arrived in the casualty department, where he was found to be anxious, dyspnoeic at rest and mildly cyanosed. His pulse was 100 beats/min, regular, and his blood pressure was $140 / 80 \mathrm{~mm} \mathrm{Hg}$. He was apyrexial, with a respiratory rate of $36 / \mathrm{min}$ and bilateral inspiratory crackles at both bases. Investigations showed a total white cell count of $21.3 \times 10^{9} / 1$ with $86 \%$ neutrophils, and normal blood urea and electrolytes. Blood gases

Correspondence: K. Sriskandan M.A., M.B., B.Chir., 4B Hall Drive, Sydenham, London SE26 6XB

Accepted: 16 January 1985 showed a $\mathrm{PO}_{2}$ of $6.3 \mathrm{kPa}$ and a $\mathrm{PCO}_{2}$ of $5.3 \mathrm{kPa}$. The chest X-ray (Figure 1) revealed gross pulmonary oedema, and the electrocardiograph showed a sinus tachycardia. The sputum showed pus cells but no pathogens, and lung function tests showed a pattern consistent with severe fixed airflow obstruction, with a low carbon monoxide transfer factor.

He was treated with intravenous frusemide, and oxygen. On transfer to the ward, oxygen was continued, first at $60 \%$, and then at $28 \%$. The following day he was started on co-trimoxazole as his sputum was purulent, and on the sixth day he was started on prednisolone, $60 \mathrm{mg} / \mathrm{d}$ which was tailed off over the following 8 weeks.

Over the next few days he made a good clinical recovery, accompanied by rapid clearing of the chest $X$-ray (Figure 2), with improvement of his blood gases and lung function tests (Table I). He made an uncomplicated recovery, and 16 months later has normal

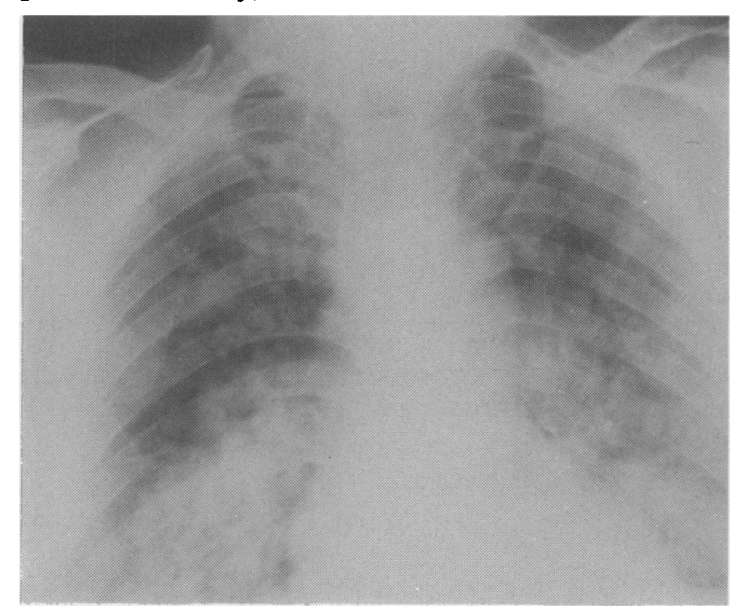

Figure 1 Chest X-ray on day of admission showing severe pulmonary oedema.

(C) The Fellowship of Postgraduate Medicine, 1985 


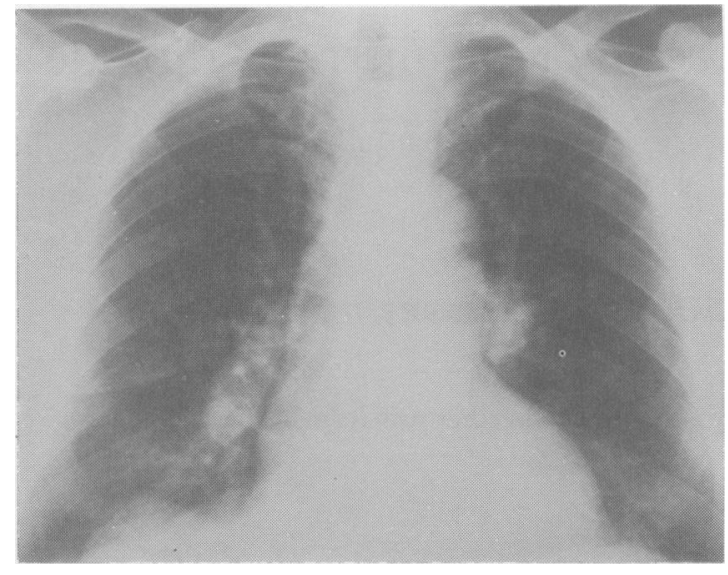

Figure 2 Chest X-ray $6 \mathrm{~d}$ post-admission showing substantial clearing of oedema.

exercise tolerance. His lung function tests continue to show a mildly obstructive picture, presumably reflecting his previous chronic bronchitis.

\section{Discussion}

Pre-decimal pennies consist of $95.5-97 \%$ copper by weight, the remainder being tin and zinc. The copper reacts with $50 \%$ concentrated nitric acid to form copper nitrate and nitrogen dioxide:

$$
\mathrm{Cu}+4 \mathrm{HNO}_{3} \rightarrow \mathrm{Cu}\left(\mathrm{NO}_{3}\right)_{2}+2 \mathrm{NO}_{2}+2 \mathrm{H}_{2} \mathrm{O}
$$

The syndrome following acute high-dose $\mathrm{NO}_{2}$ in- $\overline{3}$ halation is uncommon. An initial bout of coughing is $\stackrel{\circ}{\circ}$ followed, $3-36 \mathrm{~h}$ later, by dyspnoea, cyanosis,.. tachycardia and severe pulmonary oedema, due to $\vec{\Rightarrow}$ $\mathrm{NO}_{2}$ dissolving in the small airways to form nitric and? nitrous acids which cause a chemical pneumonitis (Prys-Roberts, 1967; McAdams, 1955). A polymor- $\frac{\bar{c}}{\bar{\omega}}$ phonuclear leucocytosis is usually present (Jones et al., $\vec{\nabla}$ 1973). If recovery from this phase occurs, the patiento may present 4-6 weeks later with a cough, cyanosises and severe dyspnoea due to bronchiolitis obliterans, $\vec{\circ}$ which may be fatal (Yockey et al., 1980; Tse \&Bockman, 1970; McAdams, 1955).

The pulmonary oedema phase is managed with? diuretics and oxygen therapy, but in addition most authors advocate a broad-spectrum antibiotic to. prevent secondary chest infection, and steroids should? be given in an attempt to prevent bronchiolitis $\triangle$ obliterans (Jones et al., 1973; Yockey et al., 1980; Tse ${ }^{\circ}$ \& Bockman, 1970; Prys-Roberts, 1967).

We would like to point out that, firstly, few seriouso coin collectors would clean their coins, and, secondly, this case illustrates the fact that even the most sedentary activities are not without their potential $\mathbb{D}$ medical hazards.

\section{Acknowledgements}

We would like to thank Dr Tim Cundy for coining the title phrase, \& the Royal Mint for kindly supplying the analysis of pre-decimal 'copper' coins and Dr D.P. Stern for the reactiono of $50 \%$ nitric acid with copper.

Table I Shows progress of blood gas results and lung function tests for $40 \mathrm{~d}$ after the acute injury

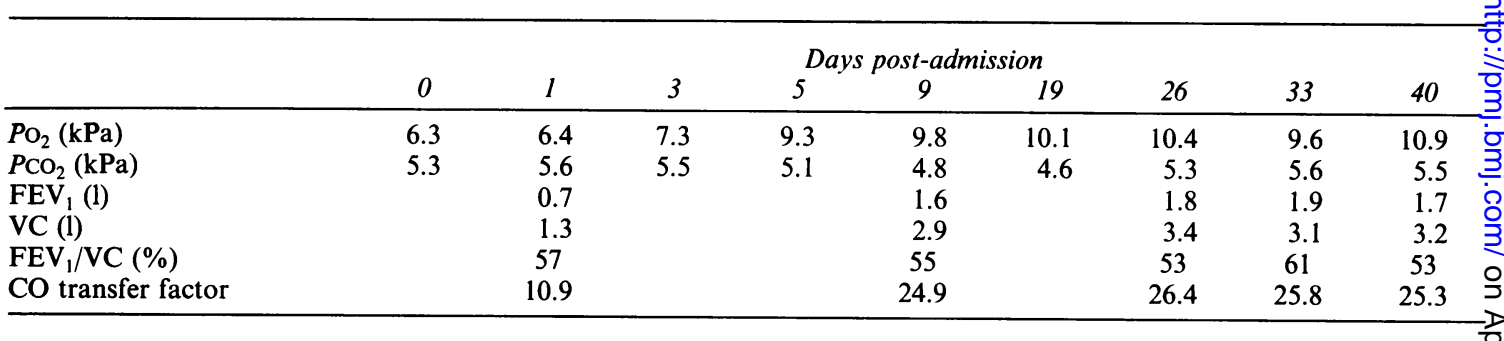

$\mathrm{FEV}_{1}=$ Forced expiratory volume in $1 \mathrm{~s} ; \mathrm{VC}=$ vital capacity; $\mathrm{CO}=$ carbon monoxide. Predicted values for a man of his height and weight are as follows: $\mathrm{FEV}_{1}, 2.4$ litres; VC, 3.7 litres and $\mathrm{CO}$ transfer factor, 22.9. 


\section{References}

JONES, G.R., PROUDFOOT, A.T. \& HALL, J.I. (1973). Pulmonary effects of acute exposure to nitrous fumes. Thorax, 28 , 61.

LOWRY, T. \& SCHUMAN, L.M. (1956). Silo-fillers' disease - A syndrome caused by nitrogen dioxide. Journal of the American Medical Association, 162, 153.

MCADAMS, A.J. JR. (1955). Bronchiolitis obliterans. American Journal of Medicine, 19, 314.

PRYS-ROBERTS, C. (1967). Principles of treatment of poison- ing by higher oxides of nitrogen. British Journal of Anaesthesia, 39, 432.

TSE, R.L. \& BOCKMAN, A.A. (1970). Nitrogen dioxide toxicity - Report of four cases in firemen. Journal of the American Medical Association, 212, 1341.

YOCKEY, C., EDEN, B.M. \& BYRD, R.B. (1980). The McConnell missile accident. Journal of the American Medical Association, 244, 1221.
. $\stackrel{\overrightarrow{\bar{C}}}{\stackrel{+}{+}}$

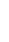

-

al

נים

